\title{
Yetiştirme ve Kariyer Algısının Çalışan Tutkunluğuna Etkisi (The Effect of Training and Career Perception on Employee Engagement)
}

\section{Saliha KILIÇ iD a Osman BAYRAKTAR iD b}

a İstanbul Ticaret Üniversitesi, Sosyal Bilimler Enstitüsü, İstanbul, Türkiye, salihaklc@gmail.com

b İstanbul Ticaret Üniversitesi, İşletme Fakültesi, İşletme Bölümü, İstanbul, Türkiye, obayraktar@ticaret.edu.tr

\begin{tabular}{ll}
\hline MAKALE BİLGİSi & ÖZET \\
\hline Anahtar Kelimeler: & Amaç - Bu araştırmanın amacı, işyerlerindeki yetiştirme ve kariyer algılarının, çalışan adanmışlı̆̆ı \\
Çalışan Tutkunluğu & üzerindeki etkisini araştırmaktır. Bu amaca yönelik olarak, araştırmanının temel denenceleri, \\
İşe Adanmışlık & işyerlerindeki yetiştirme ve kariyer uygulamalarının çalışan tutkunluğunu olumlu yönde etkilediği \\
Yetiştirme Uygulamaları & şeklinde belirlenmiştir.
\end{tabular}

Kariyer Uygulamaları

İnsan Kaynakları

Yöntem - Araştırma verileri, İstanbul'da faaliyet gösteren özel ve kamu bankaları çalışanlarından İnternet üzerinden Google.forms yazılımını kullanarak kolayda anket yöntemi ile toplanmıştır. Analizler 362 katılıcının verileri ile gerçekleştirilmiştir. Yetiştirme algısını ölçmek için Bartlett (1999), kariyer uygulamaları algısını ölçmek için Yıldız (2017), çalışan tutkunluğu algısını ölçmek için Schaufeli, Bakker ve Salanova (2006) tarafından geliştirilen ölçekler kullanılmıştır. Elde edilen verilere Gönderilme Tarihi 5 Mayıs 2021 güvenilirlik analizi, frekans analizi, normallik, faktör analizi ve çoklu regresyon analizi testleri Revizyon Tarihi 8 Ekim 2021 Kabul Tarihi 20 Ekim 2021

Makale Kategorisi: Araştırma Makalesi uygulanmıştır.

Bulgular - Regresyon analizleri sonucunda yetiştirme ve kariyer uygulamaları bağımsız değişkenlerinin çalışan tutkunluğunun dinçlik, adanmışlık ve yoğunlaşma alt boyutlarını istatiksel olarak anlamlı $(\mathrm{p}<0,05)$ ve pozitif yönde etkilediği saptanmış; test edilen 18 denencenin tamamı doğrulanmıştır.

Tartışma - Araştırma, Türkiye'de bankacıllk sektöründe gerçekleştirilmesi nedeniyle orijinaldir. Yapılan analiz ile yetiştirme ve kariyer algılarının çalışan tutkunluğu üzerinde anlamlı bir etkisinin olduğu tespit edilmiştir. Ayrıca demografik değişkenlerden yaş, kıdem ve statüye göre çalışan tutkunluğu algısı değişmekte iken eğitim seviyesi bu algıyı değiştirmediği anlaşılmıştır. Elde edilen sonuçlar incelendiğinde örneklem sayısı itibariyle bankacılık sektörü için genellenebilir büyüklüktedir. Araştırma sonuçları uygulayıcılar için de yol gösterici niteliktedir.

\section{ABSTRACT}

\section{Keywords:}

Employee Engagement

Work Engagement

Training Practices

Career Practices

Human Resources

Received 5 May 2021

Revised 8 October 2021

Accepted 20 October 2021

Article Classification:

Research Article
Purpose - The purpose of this research is to investigate the effect of training and career on employee engagement. For this purpose, the main hypotheses of the research were determined that training and career practices at workplaces positively affect employee engagement.

Design/methodology/approach - The research data were collected from private and public banking employees operating in Istanbul using an easy-to-use survey method over the Internet. The analyzes were realized with the data of 362 participants. Scales developed by Bartlett (1999) for training practices, Yildiz (2017) for career practices, and Schaufeli, Bakker, and Salanova (2006) were used to measure employee engagement. Reliability, frequency, normality test, factor analysis and multiple regression analyses were performed with the data obtained.

Findings - The goodness of fit values of the models created as a result of the analyzes were excellent, and all 18 hypotheses tested together with the sub-dimensions of the variables were accepted.

Discussion - Research is original because it was realized on the banking sector in Turkey. With the analysis made, it was determined that the perceptions of training and career had a significant effect on employee engagement. In addition, while the perception of employee engagement changes according to age, seniority and status, which are demographic variables, it is understood that education level does not change this perception. The results obtained can be generalized for the banking sector in terms of sample size, and are guiding for practitioners. 


\section{GİRIŞ}

Tutkunluk, akademik açıdan çalışanların bütün enerjileri, dinçlikleri ve yoğunlaşmayla kendilerini tam olarak işe verme durumunu ifade eder (Schaufeli vd., 2006:702). Örgütler açısından bakıldığında ise tutkunluk, çalışanlar tarafından ortaya konulan somut bir çıktı olarak görülür. Tutkun çalışanların örgütsel bağlılığ1 yüksektir, bu özelliğe sahip çalışanlar daha fazla değer yaratmanın ve yeteneklerini tam olarak kullanmanın bir yolunu bulurlar (Robertson-Smith ve Markwick, 2017:11).

Çalışan tutkunluğu ile iş performansı arasında bağlantı birçok araştırmada kanıtlanmıştır (Ogruk ve Anderson, 2018; Kapil ve Rastogi, 2017; Yongxing vd., 2017; Bhatti vd., 2018; Cartera vd., 2018; ObuobisaDarko, 2020; Ayub ve Islam, 2018). Bu nedenle yöneticiler açısından çalışan tutkunluğu etkileyen faktörlerin bilinmesi ve bu faktörlerin çalışan tutkunluğunu artıracak biçimde yönetilmesi önemlidir. Araştırmalar, işyerlerindeki yetiştirme ve kariyer faaliyetlerinin, çalışan tutkunluğunu etkileyen iki faktör olarak belirtmektedir (Semwal ve Dhyani, 2017; Johnson vd., 2018; Sawasdee vd., 2020; Chadha, 2018; Nadeem vd., 2017).

Alanyazında çokça araştııılmasına rağmen, iş sonuçlarını doğrudan etkilemesi nedeniyle, insan kaynakları yönetimi açısından çalışan tutkunluğunun bağımlı değişken olarak araştırılması önemini korumaktadır. (Tladinyane \& Merwe, 2016).

Diğer sektörlerle kıyaslandığında bankacıllk sektörünün insan kaynakları uygulamaları açısından kurumsallaşma düzeyi daha yüksektir. İnsan kaynakları birimi daha iyi örgütlenmiştir. Birçok bankada düzenli olarak çalışan memnuniyeti araştırmaları yapılmakta ve elde edilen veriler insan kaynakları süreçlerinin iyileştirilmesinde girdi olarak kullanılmaktadır. $\mathrm{Bu}$ nedenle yetiştirme ve kariyer uygulamalarının çalışan tutkunluğuna etkisi konusunda bankacılık sektöründe yapılacak bir araştırmanın araştırma modelini daha iyi destekleyeceği varsayılmıştır.

Çalışan tutkunluğu ile ilgili bugüne kadar birçok araştırma yapılmıştır. Çalışan tutkunluğu ile insan kaynakları uygulamaları ilişkisini inceleyen çalışmalar olsa da özellikle yetiştirme ve kariyer algıları ile ilişkisini konu alan araştırmalar henüz çok azdır (Nadeem, Ghani ve Shah, 2017; Siddiqui Noor-us-Sahar, 2019; Opadeyi ve Akpa, 2021). Araştırmanın literatürdeki bu alana özgün katkı yapacağı umulmaktadır.

\section{KAVRAMSAL ÇERÇEVE VE DENENCELERINN GELISSTIIRILMESİ}

\section{1. Çalışan Tutkunluğu}

$\mathrm{Bu}$ makalede çalışan tutkunluğu "employee engagement" karşılığı olarak kullanılmıştır. Alanyazında "employee engagement" (Chandani vd., 2016), "work engagement" (Green vd., 2017) ve "job engagement" (Sepahvand ve Khodashahri, 2021) kavramları ile aynı içeriğin ifade edilmek istendiği görülmektedir. Türkçe yayınlarda "employee engagemenet" karşılığı olarak "çalışanın işe tutulması" (Robbins ve Judge, 2019:78), "work engagement" karşılığ 1 olarak "işe adanmışlık" (İnce, 2016), "çalışmaya tutkunluk" (Tokmak, 2021), "işe cezbolma" (Kartal, 2018), "işe adanmışlık" (Cinnioğlu ve Saçli, 2019) "job engagemenet" karşılığı olarak "işe adanmışlık" (Öztürk ve Vatansever, 2020) kavramlarının kullanıldığı görülmektedir.

Kahn (1990) çalışan tutkunluğunu, bir kişinin, işle ilgili davranışlarında ve başkalarıyla ilişkilerinde (fiziki, bilişsel ve duygusal olarak) bütün varlığını ortaya koyması, rolünün gerektirdiği performansı eksiksiz gerçekleştirmesi durumunu ifade eder. Üç psikolojik koşulun varlığı kişilerin tutkunluklarını etkilemekte, olmadığında onları tutkunluktan uzaklaştırmaktadır. Bunlar anlamlılık, güven ve hazır bulunuşluluk boyutlarıdır. Anlamlılık, kişinin işinde ve arkadaşlarıyla ilişkide değerli hissetmesi; güven, bireyin sonuçlarından korkmaksızın kendini ortaya koyması hazır bulunuşluluk ise bireyin rolünde performans göstermesi için gerekli fiziki, duygusal ve psikolojik bütün kaynaklara sahip olma hissidir (Kahn, 1990). Green vd. (2017) işe adanmışlı̆̆ın üç kritik görünüm olduğunu belirtmektedirler: pozitif duygusal bir deneyim, bir enerji gücü ve duygusal enerjinin birincil kaynağı olan ilişkisel etkileşimler.

Maslach vd. (2001), iş tutkunluğunu, negatif bir psikolojiyi temsil eden tükenmişliğin pozitif psikolojideki karşılığı olarak konumlandırmaktadırlar. Buna göre tükenmişlik, iş tutkunluğunun azalması durumudur. Tutkunluğun üç boyutu; enerji, katılım ve yeterliliktir. Bunlar tükenmişliğin üç boyutu olan bitkinlik, siniklik, profesyonel yeterlilik eksikliğinin tam karşıtı durumlardır (Schaufeli vd., 2002). İşe tutkunluk, dinçlik, adanmışlık ve yoğunlaşma ile karakterize edilen olumlu, tatmin edici işle ilgili ruhsal bir durumdur (Schaufeli 
vd., 2006). Tutkunluk, örgütsel psikolojideki benzer kavramlar olan örgütsel bağlılık, iş tatmini ve işe katılımdan da farklı bir durumudur. Örgütsel bağlılıkta örgüte sadakate vurgu yapılırken, tutkunlukta odak noktası işin kendisidir. İş tatmininde ise iş, bir ihtiyacın karşılanmasının ve memnuniyet elde edilmesi için bir kaynaktır; kişinin işin kendisi ile olan ilişkisini kapsamaz (Maslach vd., 2001).

\subsection{Yetiştirme}

Yetiştirme, "bir faaliyette veya bir dizi faaliyette etkili performans elde etmek için, bilgi, beceri ve tutumu değiştirmek veya geliştirmek için ortaya konulan planlı ve sistematik bir çaba" olarak tanımlanır (Buckley ve Caple, 2009:9). Geliştirme ise yetiştirmeden farklı olarak daha uzun vadeli bir bakışla, gelecekte ortaya çıacak beceri ihtiyaçlarına odaklanarak çalışanların değişen iş ortamına ve örgüte uyum sağlamalarını kolaylaştırır (Bingöl, 2019:280). Yetiştirme ve geliştirme uygulamaları; iş garantisinin giderek azaldığı dönemde, çalışanları daha değerli hale getirerek onların istihdam edilebilirliğini artırır. Çalışan açısından bakıldığında, yetiştirme ve geliştirme faaliyetleri örgütün kendilerinin refah ve mutluluğu ile ilgilendiği inancını güçlendirir (Stone, 2008:360). Katılımcıların yetiştirme uygulamaları ile ilgili algısını belirleyen etkenler; öğrenme motivasyonu, eğitimden beklenen kazanç, yönetici desteği, yetiştirme fırsatları ve çalışma arkadaşları desteği başlıkları altında toplanabilir (Bartlett, 1999; Sabuncuoğlu, 2007).

Bangladeş'te (Siddiqui ve Sahar, 2019) ve Pakistan'da (Rashid vd., 2011), bankacılık sektöründe, Hindistan'da üretim sektöründe (Saxena ve Srivastava, 2015) yetiştirme uygulamaları ile çalışan adanmışlığı arasında kuvvetli ilişki olduğu, Ürdün'de havacılık sektöründe yapılan araştırmada (Alola ve Alafeshat, 2021) yetiştirme ve geliştirme uygulamalarının çalışan adanmışlığını etkilediği saptanmıştır. Pakistan'da bankacılık sektöründe yapılan bir araştırmada, çalışan adanmışlığının örgütsel performans ile eğitim ve geliştirme uygulamaları ilişkisinde aracılık rolü oynadığı bulunmuştur (Chaudhry vd., 2017). Yeterli eğitim olanağı sağlandığı takdirde çalışanların iş gereklikleri ile başa çıkabilmeleri kolaylaşmaktadır. Böylece çalışanlar işleri ile ilgili talepleri karşılayabileceklerini inandıklarından işe olan tutkuları da artmaktadır (Memon vd., 2016).

Öğrenme motivasyonu, katılımcıların eğitim programlarının içeriğini öğrenmeye olan arzularıdır (Noe, 2009:64). İşletmelerde eğitim alan kimseler yetişkin grubundadır. Yetişkinler, öğrenmenin doyuracağı ilgi alanları doğrultusunda motive olurlar (Knowles, Swanson ve Holton, 2015:47). Bucley ve Caple (2009) katılımcının öğrenme motivasyonu ile öğrenilecek konunun zorluk düzeyi ilişkisine dikkat çekmektedirler. Katılımcılar tarafından çok zor veya çok kolay olarak algılanan eğitimlerde yüksek öğrenme motivasyonu başarısızlığa yol açabilmektedir. Öğrenme motivasyonu ile performans arasındaki en yüksek ilişki katılımcılar tarafından orta derecede zor olarak algılanan eğitimlerde gerçekleşmektedir (Buckley ve Caple, 2009:141). Bu bilgilerden hareketle aşağıdaki hipotezler geliştirilmiştir:

$$
\begin{aligned}
& \text { H1.1: Öğrenme motivasyonu, dinçlĭgi anlamlı ve olumlu yönde etkiler. } \\
& \text { H1.2: Öğrenme motivasyonu, adanmışlı̆̆ı anlamlı ve olumlu yönde etkiler. } \\
& \text { H1.3: Öğrenme motivasyonu, yoğunlaşmayı anlamlı ve olumlu yönde etkiler. }
\end{aligned}
$$

Algılanan kazançlar. Çalışanların eğitim programına katılmaktan üç farklı kazanç bekledikleri belirtilmektedir: Öğrenme motivasyonunun gelişmesi (örneğin daha fazla eğitime katılma ve öğrenme arzusu), kariyer gelişimi (örnek; terfi ve daha ilginç görevlendirmeler) ve psikolojik gelişme (örnek, kendini gerçekleştirme ve örgüt ilişki ağına katılmak için yeteneğinin artması) (Noe ve Wilk, 1993). Bu bilgilerden hareketle aşağıdaki hipotezler geliştirilmiştir:

\section{H1.4: Yetiştirmeden beklenen bireysel kazançlar, dinçliği anlamlı ve olumlu yönde etkiler.}

H1.5: Yetiştirmeden beklenen bireysel kazançlar, adanmışlğ̆l anlaml ve olumlu yönde etkiler.

H1.6: Yetiştirmeden beklenen bireysel kazançlar, yoğunlaşmayı anlamlı ve olumlu yönde etkiler.

Yönetici desteğinin, eğitime katılımı ve uygulamayı destekleme olmak üzere iki boyutu bulunmaktadır. Birinci aşamada yöneticinin vereceği destek, çalışanın eğitime katılmasına izin vermesidir. İkinci aşamadaki desteği ise katılımcıların eğitimde edindikleri bilgileri uygulamaya aktarmalarına izin vermesidir (Noe, 2009:137).

H..: Yetiştirme için alğlanan yönetici desteği, dinçliği anlamlı ve olumlu yönde etkiler. 
S. Kılıç - O. Bayraktar 13/4 (2021) 3026-3043

H1.8: Yetiştirme için algılanan yönetici desteği, adanmışlı̆̆ı anlamlı ve olumlu yönde etkiler.

H1.9: Yetiştirme için alg̨lanan yönetici desteği, yoğunlaşmayı anlamlı ve olumlu yönde etkiler.

Algılanan eğitim fırsatları, bütün çalışanların işletmenin sunduğu eğitim fırsatlarına ulaşabilme durumunu ifade eder (Sabuncuoğlu, 2007). Şayet çalışanlar eğitim fırsatlarının yüksek olarak algılarlarsa kendilerine teklif edilen bütün eğitimlere katılmayı, bir baskı hissetmeden gönüllü olarak kabul edeceklerdir (Dysvik ve Kuvaas, 2008). Bu bilgilerden hareketle aşağıdaki hipotezler geliştirilmiştir:

H1.10: Algılanan yetiştirme firsatları, dinçliği anlamlı ve olumlu yönde etkiler.

H1.11: Algılanan yetiştirme firsatları, adanmışlğ̆l anlaml ve olumlu yönde etkiler.

H1.12: Algzlanan yetiştirme firsatları, yoğunlaşmayı anlamlı ve olumlu yönde etkiler.

Çalışma arkadaşları desteği, katılımcıların eğitimde öğrendikleri bilgi ve becerileri geliştirme ve uygulamaya amacıyla gruplar oluşturmalarıdır. İki veya daha fazla kişiden oluşan bu gruplarda çalışanlar, eğitim içeriğini işe aktarma deneyimlerini, bu aşamada karşılaştıkları fırsatları ve zorlukları paylaşırlar (Noe, 2009:140).

H1.13: Yetiştirme için algılanan çalışma arkadaşları desteği, dinçlĭgi anlamlı ve olumlu yönde etkiler.

H1.14: Yetiştirme için algılanan çalışma arkadaşları desteği, adanmışlı̆̆ı anlamlı ve olumlu yönde etkiler.

H.15: Yetiştirme için algılanan çalışma arkadaşları desteği, yoğunlaşmayı anlamlı ve olumlu yönde etkiler.

\subsection{Kariyer Kavramı ve Kariyer Geliştirme Uygulamaları}

Kariyer, seçilmiş bir meslek, uzmanlık alanı ve kişinin çalışma hayatı ya da mesleki başarılarındaki genel gidişatı, ilerlemeleri olarak tanımlanabilir (Alnıaçık, 2013:276). Kariyer, uygulamada, kariyer planlama ve kariyer geliştirme olarak iki görünümle ortaya çıkmaktadır. Kariyer planlama, kariyerin çalışan merkezli yanına, kariyer geliştirme ise örgüt merkezli yanına işaret eder. İdeal olan kariyer planlama ve kariyer geliştirme faaliyetlerinin hizalanmış süreçler olarak yönetilmesidir (Stone, 2008:395).

Örgütlerde çalışanların kariyerlerini geliştirmek için örgüt içi boş pozisyonların çalışanlara duyurulması, çalışanlara kariyer geliştirme amacına yönelik biçimsel eğitimler verilmesi ve fonksiyonlara arası yatay hareketlilik kullanılan başlıca yöntemlerdir (Budak, 2016, s. 326). Bazı işletmelerde çalışanların işletme içindeki fırsat ve pozisyonları daha yakından tanımaları için kariyer danışmanlığı hizmetleri, bireyleri desteklemek için mentorluk uygulamaları bulunmaktadır. Yedekleme planlaması açısından özellikle kritik görülen yöneticilik pozisyonlarına hazırlanması öngörülen adayların uygunluk ve yeterliliklerini belirlemek için değerlendirme merkezi aracı kullanılmaktadır (Bingöl, 2019: 349-355).

Alanyazında, farklı ülkelere ve farklı sektörlerde gerçekleştirilmiş kariyer uygulamaları ile çalışan tutkunluğu ilişkisini araştıran çok sayıda çalışma bulunmaktadır. Nijerya'da bankacılık sektöründe (Opadeyi ve Akpa, 2021), Güney Afrika'da bir sigorta şirketinde (Tladinyane ve Merwe, 2016) Pakistan'da bankacılık sektöründe (Ali vd., 2019; Nadeem vd., 2017), Suudi Arabistan'da medya sektöründe (Alabooda ve Manakkattilb, 2020) yapılan araştırmalarda kariyer ve geliştirme uygulamaları ile çalışan tutkunluğu arasında kuvvetli ilişki saptanmıştır. Bu araştırmalardan hareketle aşağıdaki hipotezler oluşturulmuştur.

$\mathrm{H}_{2}$ : Kariyer uygulamaları, çalışan tutkunluğunu olumlu yönde etkilemektedir.

H.1: Kariyer uygulamaları, dinçlĭği olumlu yönde etkiler.

H2.2: Kariyer uygulamaları, adanmışlı̆̆ı olumlu yönde etkiler.

H2.3: Kariyer uygulamaları, yoğunlaşmayı olumlu yönde etkiler. 


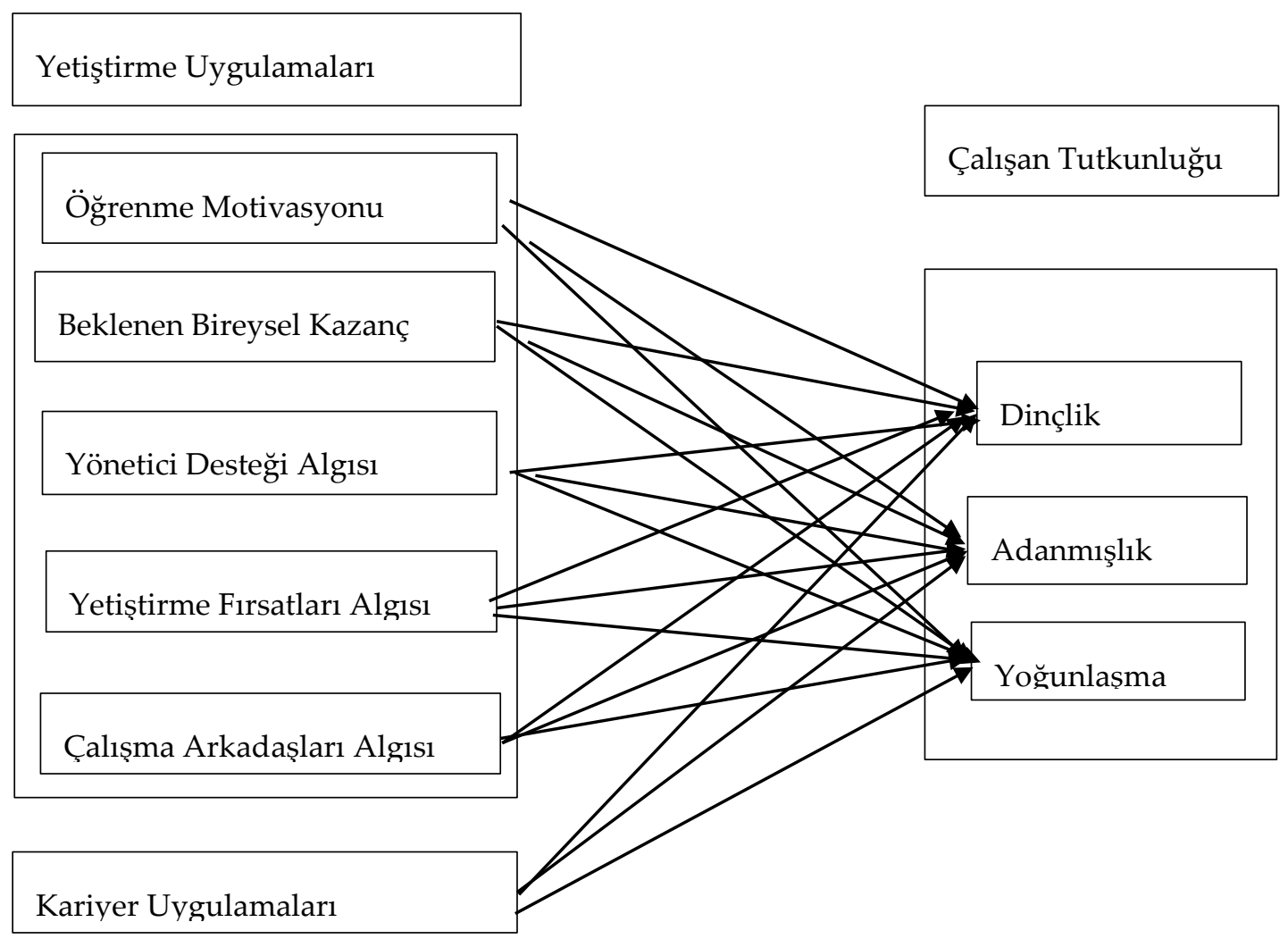

Şekil 1. Hipotezlerin Özetlenmesi

\section{YÖNTEM}

\subsection{Araştırmanın Yöntemi}

Araştırma verileri, bankalarda çalışan kişilerden İnternet üzerinden Google.forms yazılımı aracılığıyla kolayda örneklem yöntemi ile toplanmıştır. Anket formunda üç ayrı ölçeği kapsayan 65 ifade ile katılımcıların demografik özelliklerine dair 6 soru bulunmaktadır.

\subsection{Araştırma Kütlesi ve Örneklem Büyüklü̈̆̈̈̈}

Araştırma verileri İstanbul'da görev yapan banka çalışanlarından toplanmıştır. Veri toplamda kamu ve özel banka ayırımı yapılmamıştır. Anket formunda katılımcıların çalıştığı banka sorusu yer almamaktadır. İnternet ortamında gerçekleştirilen veri toplama işleminde 362 kişiden eksiksiz geri dönüş sağlamıştır. Araştırma modelinde yer alan iki bağımsız değişkedeki ifade sayısı toplam olarak $48^{\prime}$ dir. İstatistik analiz için, örneklem büyüklügünün, bağımsız değişkenlerdeki ifadelerin 4 ya da 5 katı olması en iyi durum olarak kabul edilmektedir (Çokluk vd., 2018:110). Bu varsayıma göre nitelikli istatistik analizlerin yapılması için 240 örneklem büyüklüğü yeterlidir.

\subsection{Veri Toplama Aracı ve Yöntemi}

Araştırmada katılımcıların çalıştıkları kurumlardaki yetiştirme algılarını ölçmek için Bartlett (1999) tarafından oluşturulan ve daha önce Türkçede farklı araştırmacılar tarafından (Sabuncuoğlu, 2007; Yıldız, 2011; Tanışman, 2018) kullanılan ölçek kullanılmıştır. Yıldız'ın adapte ettiği biçimiyle yetiştirme ölçeğinde 30 ifade yer almaktadır. Ölçekte Algılanan Yetiştirme Olanakları (dört ifade), Yönetici Desteği (beş ifade), Çalışma Arkadaşları Desteği (beş ifade), Öğrenme Motivasyonu (beş ifade), Yetiştirmeden Beklenen Bireysel Kazançlar (altı ifade) ve Yetiştirmeden Beklenen Kariyer Olanakları (beş ifade) olmak üzere altı alt boyut bulunmaktadır. Beş düzeyli Likert tipi ölçekte değerlendirme ifadeleri 1- Hiç katılmıyorum, 5- Tamamen katılıyorum şeklinde düzenlenmiştir.

Kariyer algılarını değerlendirmek için Yıldız (2017) tarafından geliştirilen ölçek kullanılmıştır (s. 109). Ölçek ifadelerinde sektöre uygun şekilde düzeltmeler yapılmıştır. Ölçekte 18 ifade yer akmaktadır. Ölçekte Gelişmeye Yönelik Faaliyetler (dokuz ifade) ve Biçimsel Faaliyetler (dokuz ifade) olarak isimlendirilen iki alt 
boyut bulunmaktadır. Beş düzeyli Likert tipi ölçekte değerlendirme ifadeleri 1- Hiç katılmıyorum, 5Tamamen katılıyorum şeklinde düzenlenmiştir.

Katılımcıların çalışan tutkunluğu düzeyini ölçmek için tarafından geliştirilen UWES ölçeği kullanılmıştır (Schaufeli ve vd. , 2002; Schaufeli ve Bakker, 2004:48; Schaufeli vd., 2006:702). Türkçeye Turgut (2011) tarafından çevrilen UWES ölçeğinde toplam 17 ifade bulunmaktadır. Ölçeğin; dinçlik (altı ifade), adanmışlık (beş ifade) ve yoğunlaşma (altı ifade) olarak isimlendirilen üç alt boyutu bulunmaktadır. Altı düzeyli ölçekte değerlendirme etiketleri 1- Hiçbir zaman, 6- Her zaman şeklindedir.

Anket veriler 5.10.2020 - 22.12.2020 tarihleri arasında elektronik ortamda online olarak toplanmıştır. Araştırma için İstanbul Ticaret Üniversitesi Etik Kurulundan 09.09.2020 tarih ve 65836846-044 sayılı yazı ile Etik Onayı alınmıştır.

\section{ANALIZZ VE BULGULAR}

\subsection{Yetiştirme Ölçeği}

Yetiştirme Ölçeği Açıklayıcı Faktör Analizine Ait Bulgular. Faktör analizinin ön şartları olan, Bartlett Küresellik Testi sonucuna göre değişkenler arasında yeterli ilişki bulunmuştur $(\mathrm{p}<0,05)$. Kaiser-Meyer-Olkin (KMO) değerinin kabul edilebilir alt değer olan 0,60'ın üzerinde olması gerekmektedir. KMO değeri örneklem sayısının faktör analizi için yeterliliğini ölçtüğünden katılımcı sayısının faktör analizi yapmaya yeterli olduğu belirlenmiştir. (KMO=0,893). Ölçekteki ifadelerin faktör ağırlıkları 0,43-0,868 arasındadır.

Faktör analizi sonucunda, yetiştirme uygulamaları ölçeği 5 faktör altında toplanmış ve bu 5 faktör toplam varyansın \%68,344'ünü açıkladığı belirlenmiştir. Faktör yüklerine göre maddelerin toplandıkları faktörlerdeki yüklerin birbirine uzaklığının en az \%10 olması gerektiğinden, birden fazla faktörde yer aldığı için madde 4 analiz dışı bırakılmıştır. Faktörlerin içsel tutarlılıklarının hesaplanmasında, Cronbach alfa değeri kullanılmıştır. Cronbach alfa değerinin 0.70 'in üzerinde olduğundan güvenirliğin yüksek olduğunu belirlenmiştir.

Yetiştirme Ölçeğinin Doğrulayıcı Faktör Analizine Ait Bulgular. Yetiştirme uygulamaları ölçeğine ait doğrulayıcı faktör analizi (DFA) ile ilgili ölçeğe ait DFA yol diyagramı Şekil 2' deki gibidir. 


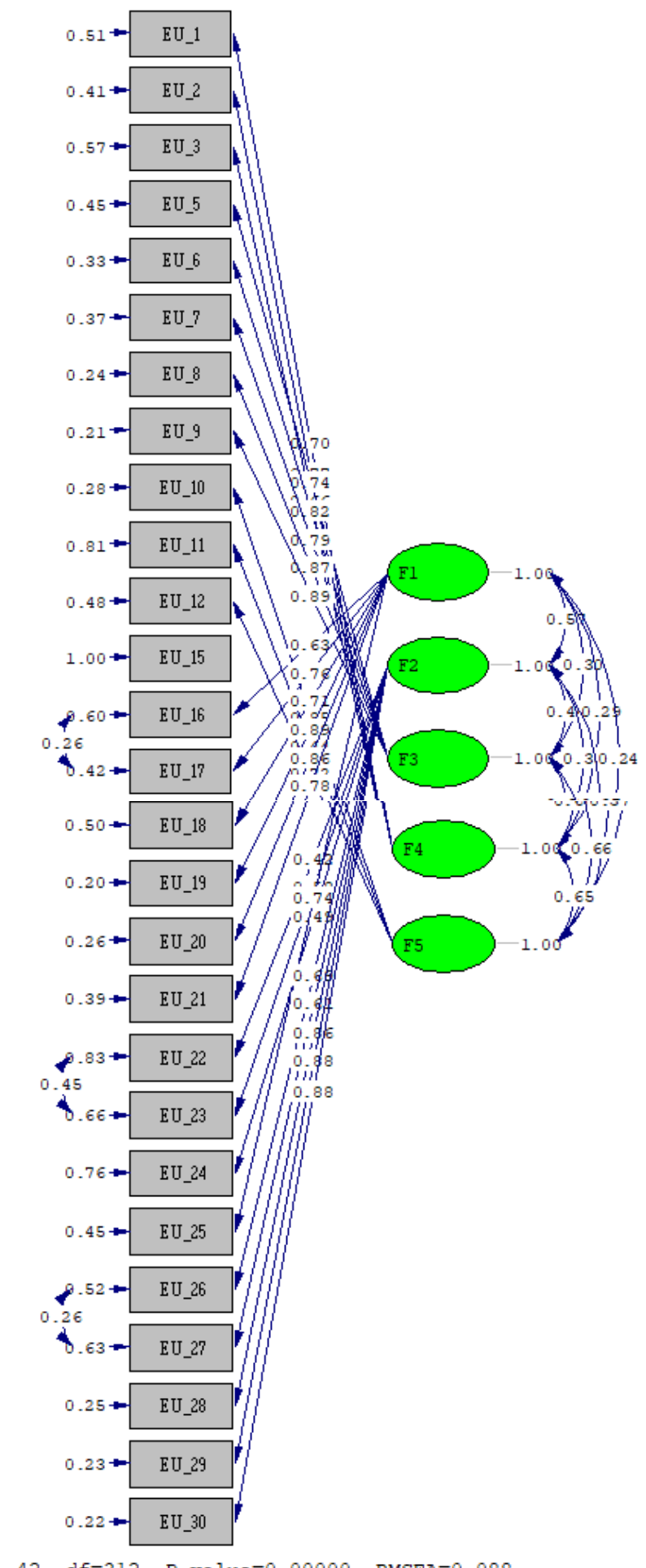

.42, $\mathrm{df}=312, \mathrm{P}$-value $=0.00000, \mathrm{RMSEA}=0.088$

Şekil 1. Yetiştirme uygulamaları ölçeğine ait DFA sonucu

YEM uygulamasında test edilen modelin bir bütün olarak toplanan veri ile desteklenip desteklenmediğine, analizler sonucunda ortaya çıkan uyum iyiliği değerlerine bakılarak karar verilmektedir. YEM analizlerinde yaygın olarak kullanılan uyum indeksleri ve bunların kabul edilebilir eşik değerleri Tablo 1'de gösterilmiştir. 
S. Kılıç - O. Bayraktar 13/4 (2021) 3026-3043

Tablo 1. YEM'de Kullanılan Uyum İyiliği İndeksleri ve Eşik Değerleri

\begin{tabular}{llc}
\hline \hline İncelenen Uyum İndeksleri & Mükemmel Uyum & Kabul Edilebilir Uyum \\
\hline$\chi 2 /$ sd & $0 \leq \chi 2 /$ sd $\leq 2$ & $2 \leq \chi 2 /$ sd $\leq 3$ \\
RMSEA & $0,00 \leq$ RMSEA $\leq 0,05$ & $0,05 \leq$ RMSEA $\leq 0,08$ \\
NFI & $0,95 \leq$ NFI $\leq 1.00$ & $0,90 \leq \mathrm{NFI} \leq 0,95$ \\
NNFI & $0,95 \leq \mathrm{NNFI} \leq 1,00$ & $0,90 \leq \mathrm{NNFI} \leq 0,95$ \\
CFI & $0,95 \leq \mathrm{CFI} \leq 1,00$ & $0,90 \leq \mathrm{CFI} \leq 0,95$ \\
IFI & $0,95 \leq \mathrm{IFI} \leq 1,00$ & $0,90 \leq \mathrm{IFI} \leq 0,95$ \\
\hline
\end{tabular}

Kaynak: İlhan ve Çetin, 2014.

İlk analizde RMSEA değerinin =,80'in üzerinde çıkması nedeniyle ölçeğin 16 ve 17, 22 ve 23 , 26 ve 27 numaralı maddeleri arasında modifikasyon yapılmıştır. Düzeltme yapılan ifadelerin teorik olarak birbirleriyle ilişkili oldukları saptanmıştır. Ölçekteki 13. ve 14. ifadeler faktör yüklerinin düşük olması analiz dışı bırakılmıştır. Bu düzeltmeler sonucunda ölçüm modelinin uyum iyilik değerleri $(\chi 2 / \mathrm{sd}=3,78$, RMSEA $=, 080, \mathrm{NFI}=0,92$, $\mathrm{NNFI}=0,92, \mathrm{CFI}=0,94, \mathrm{IFI}=0,94)$ olarak gerçekleşmiştir. Bazı kaynaklarda $\chi 2 /$ sd değerinin 3-5 olması durumunda arasında olması modelin kabul edilebilir olduğu belirtilmektedir (Gürbüz, 2019, s. 35). Bu verilere göre modelin uyum iyilik değerleri kabul edilebilir sınırlardadır.

Yapılan modifikasyon ve iki maddenin çıkarılmasından sonra, ölçek beş alt boyutlu olarak değerlendirilmiştir. Ölçeğin yakınsak geçerliliğini test etmek için kompozit güvenilirlik (CR) ve ortalama açılanan varyans (AVE) değerlerine bakılmıştır. Yakınsak geçerlilik değişkenlere ilişkin ifadelerin birbirleriyle ve oluşturdukları ilişkili olduklarını ifade eder. Yakınsak geçerlilik için ölçeğe ilişkin CR değerinin AVE değerinin karekökünden büyük olması beklenir. AVE değeri en az 0,50 beklendiğinden ve 0,50 'nin karekökü de 0,707 olduğundan CR değerinin 0,70'ten büyük olması beklenir (Yaşlığlu, 2017). Tablo 2' de görüldüğü üzere tüm boyutlarda CR değerleri AVE değerlerinin üzerindedir. Faktör 5'in dışında diğer alt boyutlarda da AVE değerleri kabul edilebilir eşiğin $(0,50)$ üzerindedir.

Tablo 2. Yetiştirme Uygulamaları Ölçeği CR ve AVE Değerleri

\begin{tabular}{|c|c|c|c|}
\hline Boyutlar & Madde & CR & AVE \\
\hline Faktör 1: Öğrenme Motivasyonu & $15-16-17-18-19-20-21-25$ & 0.918 & 0.590 \\
\hline Faktör 2: Yetiştirmeden Beklenen Kariyer Beklentileri & $22-23-24-26-27-28-29-30$ & 0.893 & 0.582 \\
\hline Faktör 3: Yetiştirme İçin Algılanan Yönetici Desteği & $4-5-6-7-8-9$ & 0.921 & 0.664 \\
\hline Faktör 4: Algılanan Yetiştirme Olanakları & $1-2-3$ & 0.763 & 0.534 \\
\hline Faktör 5: Yetiştirme İçin Algılanan Çalışma Arkadaşları Desteği & $10-11-12$ & 0.704 & 0.434 \\
\hline
\end{tabular}

\subsection{Kariyer Ölçeği}

Kariyer Ölçeği Açıklayıcı Faktör Analizine Ait Bulgular. Faktör analizinin ön şartları olan, Bartlett Küresellik Testi sonucuna göre değişkenler arasında yeterli ilişki bulunmuştur ( $<<0,05, p=0,000)$. KMO değeri örneklem sayısının faktör analizi için yeterliliğini ölçtüğünden katılımcı sayısının faktör analizi yapmaya yeterli olduğu belirlenmiştir. $(\mathrm{KMO}=0,943)$. Ölçekteki ifadelerin faktör ağırlıkları 0,774 -0,685 arasındadır.

Faktör analizi sonucunda, kariyer uygulamaları ölçeği, orijinal ölçekten farklı olarak tek faktör altında toplanmıştır. Faktörün, toplam varyansın \%63,251'ini açıkladığı görülmektedir. Faktör analizinde birden fazla faktörde yer alan 2, 3, 4, 5, 10 ve 18. ifadeler analiz dışı bırakılmıştır. Faktörlerin içsel tutarlılıklarını gösteren Cronbach alfa değerinin 0.70 'in üzerinde olduğundan ölçeğin güvenirliğin yüksek olduğu belirlenmiştir. 
Kariyer Uygulamaları Ölçeğinin Doğrulayıcı Faktör Analizine Ait Bulgular. Kariyer uygulamaları ölçeğine ait doğrulayıcı faktör analizi ile ilgili ölçeğe ait DFA yol diyagramı Şekil 3'de gösterilmektedir.

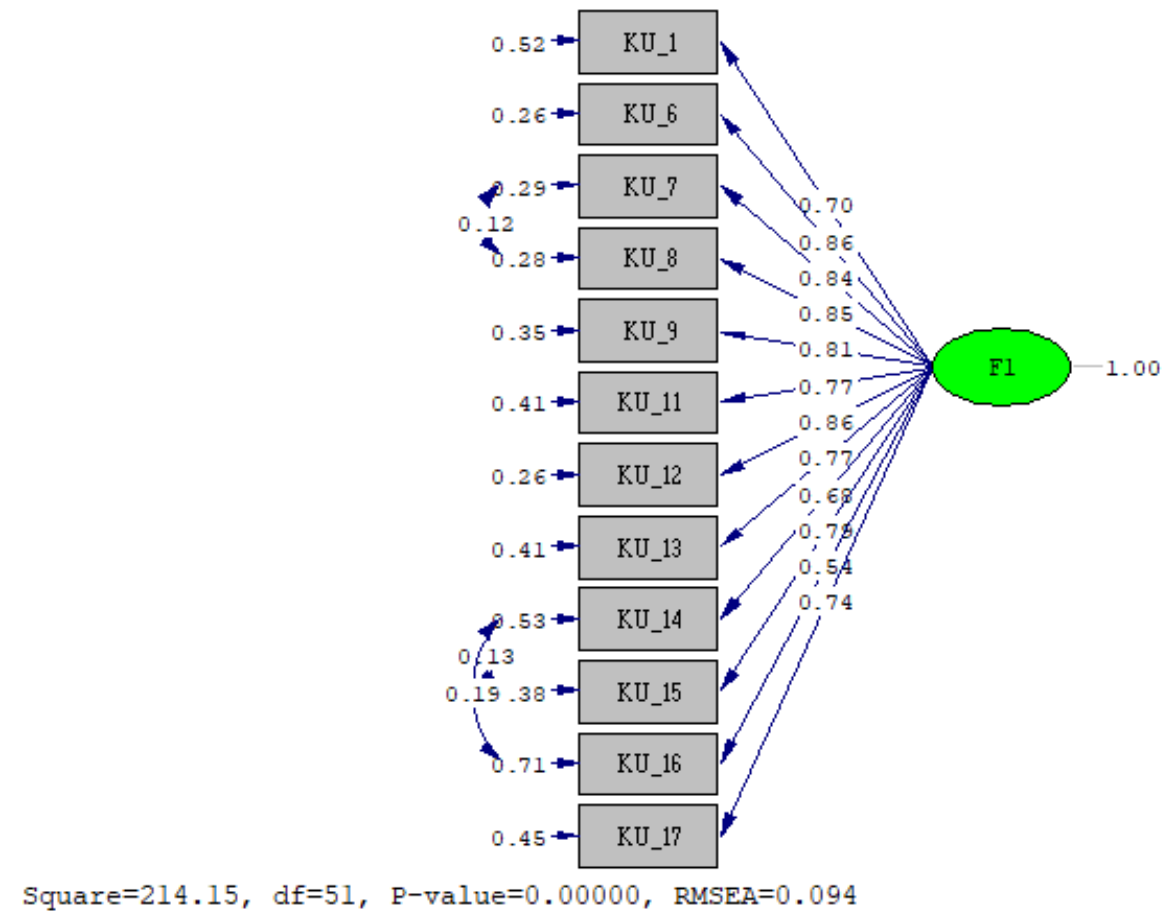

Şekil 2. Kariyer uygulamaları ölçeğine ait DFA sonucu

Şekil 3 incelendiğinde, geliştirilen ölçeğe ait uyum kriterlerinin ilk aşamada istenilen düzeyde çıkmaması sebebiyle 7- 8, 14- 16 ve 15- 16 maddeleri arasında modifikasyon yapılmıştır. Düzeltme yapılan ifadeler teorik olarak birbiriyle uyumludur. Düzeltmelerden sonra, ölçüm modelinin uyum iyilik değerleri $(\chi 2 / \mathrm{sd}=2,28$, RMSEA $=0,094, \mathrm{NFI}=0,97, \mathrm{NNFI}=0,97, \mathrm{CFI}=0,98, \mathrm{IFI}=0,98$ ) olarak gerçekleşmiştir. RMSEA değerinin $0,08^{\prime}$ in altında olması beklenir. Bazı kaynaklarda 0,08-0,10 arasındaki RMSEA değerinin vasat olmakla birlikte hâlâ kabul edilebilir olduğu belirtilmektedir (Gürbüz, 2019, s. 36). Kariyer ölçeğinin geçerlilik göstergeleri olan $C R=$ 0.946; $\mathrm{AVE}=0.60$ olarak çıkmıştır. $\mathrm{CR}$ değeri $\mathrm{AVE}$ değerini üzerinde, $\mathrm{AVE}$ değeri $=0,50^{\prime}$ den büyüktür. $\mathrm{Bu}$ verilere göre uyum iyilik değerlerinin kabul edilebilir sınırlar içinde olduğu söylenebilir.

\section{3. Çalışan Tutkunluğu Ölçeği}

Çalışan Tutkunluğu Ölçeği Açıklayıcı Faktör Analizine Ait Bulgular. Bartlett Küresellik Testi sonucuna göre değişkenler arasında yeterli ilişki bulunmaktadır $(\mathrm{p}<0,05, \mathrm{p}=0,000)$. KMO değeri mükemmel seviyededir $(\mathrm{KMO}=0,905)$. Ölçekteki ifadelerin faktör ağırlıkları 0,717 ile 0,878 arasındadır.

Faktör analizi sonucunda, çalışan tutkunluğu ölçeğindeki ifadeler, orijinal ölçekteki gibi üç alt boyut altında toplanmıştır. Bu üç alt boyut toplam varyansın \%71,859'unu açıklamaktadır. Faktör analizinde birden fazla faktörde yer alan 2. ve 17. ifadeler analiz dışı bırakılmıştır. Faktörlerin içsel tutarlılıklarını gösteren Cronbach alfa değerinin 0.70 'in üzerinde olduğundan güvenirliğin yüksek olduğunu belirlenmiştir.

Çalışan Tutkunluğu Ölçeğinin Doğrulayıcı Faktör Analizine Ait Bulgular. Çalışan tutkunluğu ölçeğine ait doğrulayıcı faktör analizi ile ilgili ölçeğe ait DFA yol diyagramı Şekil 4'te gösterilmektedir. 


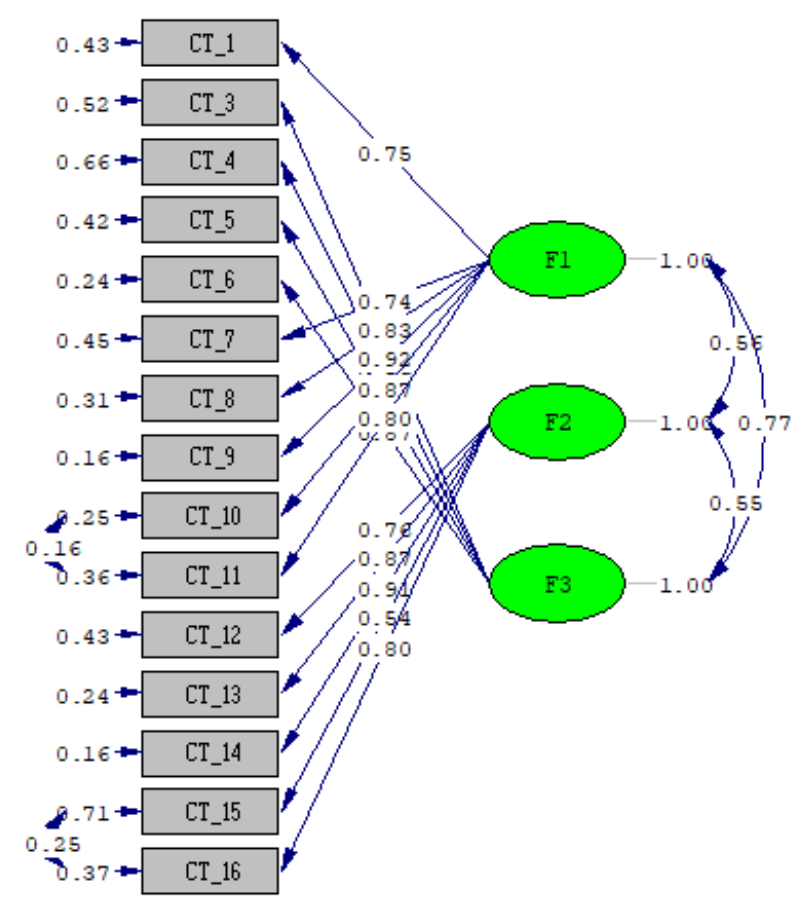

Şekil 3. Çalışan tutkunluğu ölçeğine ait DFA sonucu

Şekil 4 incelendiğinde, geliştirilen ölçeğe ait uyum kriterleri ilk aşamada istenilen düzeyde çıkmaması sebebiyle CT_10-CT_11 ve CT_15-CT_16 maddeleri arasında modifikasyon yapılmıştır. Düzeltme yapılan ifadeler teorik olarak birbirleriyle uyumludur. . Düzeltmeden sonra ölçüm modelinin uyum iyilik değerleri şöyledir: $\chi 2 / \mathrm{sd}=3,85, \mathrm{RMSEA}=, 080, \mathrm{NFI}=0,96, \mathrm{NNFI}=0,97, \mathrm{CFI}=0,97, \mathrm{IFI}=0,97$. Bazı kaynaklarda 3-5 arasındaki : $\chi 2 / s d$ değerinin kabul edilebilir olduğu belirtilmektedir (Gürbüz, 2019, s. 34). Bu sonuçlara göre uyum iyilik kriterleri kabul edilebilir aralıklardadır. Faktör analizi sonucunda 1. faktör altında toplanan maddeler incelendiğinde faktör 1 'e "Adanmışlık" adı verilmiştir. 2. faktör altında toplanan maddeler incelendiğinde faktör 2'ye "Yoğunlaşma", 3. faktör altında toplanan maddeler incelendiğinde ise faktör 4'te "Dinçlik" adı verilmiştir. Çalışan Tutkunluğu Ölçeğine ait CR ve AVE değerleri ise Tablo 3'te belirtilmiştir. Tüm boyutlarda CR değerleri AVE değerlerinin üzerinde, AVE değerleri de 0,50 'den büyüktür.

Tablo 3. Çalışan Tutkunluğu Ölçeği CR ve AVE Değerleri

\begin{tabular}{lccc}
\hline \hline \multicolumn{1}{c}{ Boyutlar } & Madde & CR & AVE \\
\hline Faktör 1: Adanmışlık & $1-7-8-9-10-11$ & 0.926 & 0.678 \\
Faktör 2: Yoğunlaşma & $12-13-14-15-16$ & 0.888 & 0.621 \\
Faktör 3: Dinçlik & $3-4-5-6$ & 0.831 & 0.568 \\
\hline
\end{tabular}

Tablo 4'de ise modelin uyum indeksleri gösterilmektedir. 
Tablo 4. Modelin Uyum indeksleri

Uyum indeksleri

\begin{tabular}{|c|c|c|c|c|c|c|c|c|c|}
\hline Modeller & $X^{2}$ & sd & $\mathrm{X}^{2} / \mathrm{sd}$ & p & RMSEA & SRMR & NFI & NNFI & CFI \\
\hline Öğrenme Motivasyonu> Adanmışlık & 263,10 & 61 & 4,31 & 0,000 & 0,096 & 0,049 & 0,96 & 0,96 & 0,97 \\
\hline Öğrenme Motivasyonu> Yoğunlaşma & 294,11 & 61 & 4,82 & 0,000 & 0,103 & 0,047 & 0,95 & 0,95 & 0,96 \\
\hline Öğrenme Motivasyonu> Dinçlik & 192,40 & 50 & 3,85 & 0,000 & 0,089 & 0,047 & 0,96 & 0,96 & 0,97 \\
\hline Beklenen Bir. Kazanç Algısı> Adanmışlık & 265,93 & 63 & 4,22 & 0,000 & 0,094 & 0,061 & 0,95 & 0,95 & 0,96 \\
\hline Beklenen Bir. Kazanç Algısı> Yoğunlaşma & 267,20 & 63 & 4,24 & 0,000 & 0,095 & 0,059 & 0,94 & 0,94 & 0,95 \\
\hline Beklenen Bir. Kazanç Algısı> Dinçlik & 185,53 & 52 & 3,57 & 0,000 & 0,084 & 0,061 & 0,95 & 0,95 & 0,96 \\
\hline Yönetici Desteği Algısı> Adanmışlık & 228,27 & 52 & 4,38 & 0,000 & 0,092 & 0,050 & 0,96 & 0,97 & 0,97 \\
\hline Yönetici Desteği Algısı> Yoğunlaşma & 135,71 & 42 & 3,23 & 0,000 & 0,079 & 0,052 & 0,97 & 0,97 & 0,98 \\
\hline Yönetici Desteği Algısı> Dinçlik & 104,80 & 34 & 3,08 & 0,000 & 0,076 & 0,047 & 0,97 & 0,97 & 0,98 \\
\hline Eğitim Fırsatları Algısı> Adanmışlık & 88,07 & 24 & 3,67 & 0,000 & 0,086 & 0,035 & 0,97 & 0,97 & 0,98 \\
\hline Eğitim Fırsatları Algısı> Yoğunlaşma & 41,50 & 18 & 2,31 & 0,000 & 0,060 & 0,029 & 0,98 & 0,98 & 0,99 \\
\hline Eğitim Fırsatları Algısı> Dinçlik & 18,85 & 13 & 1,45 & 0,000 & 0,035 & 0,033 & 0,98 & 0,99 & 0,99 \\
\hline Çalışma Ark. Desteği Algısı> Adanmışlık & 84,75 & 23 & 3,68 & 0,000 & 0,086 & 0,063 & 0,97 & 0,97 & 0,98 \\
\hline Çalışma Ark. Desteği Algısı> Yoğunlaşma & 64,50 & 18 & 3,58 & 0,000 & 0,085 & 0,040 & 0,97 & 0,96 & 0,98 \\
\hline Çalışma Ark. Desteği Algısı> Dinçlik & 17,97 & 13 & 1,38 & 0,000 & 0,033 & 0,043 & 0,98 & 0,99 & 0,99 \\
\hline Kariyer Uygulamaları> Adanmışlık & 553,76 & 132 & 4,20 & 0,000 & 0,094 & 0,052 & 0,96 & 0,97 & 0,97 \\
\hline Kariyer Uygulamaları> Yoğunlaşma & 503,48 & 117 & 4,30 & 0,000 & 0,096 & 0,048 & 0,96 & 0,96 & 0,97 \\
\hline Kariyer Uygulamaları> Dinçlik & 390,04 & 102 & 3,82 & 0,000 & 0,088 & 0,048 & 0,96 & 0,97 & 0,97 \\
\hline
\end{tabular}

Model anlamlı: $\mathrm{P}<0,01$

Model uygunluğu: $\mathrm{X}^{2} / \mathrm{sd}<5,0$

Tablo 4'te belirtildiği üzere modeller için hesaplanan beta katsayılarının anlamlı olduğu görülmektedir.

\subsection{Normallik Analizi}

Ölçeklerde bulunan beşli veya yedili maddelerin normal dağıldığına ilişkin varsayım değişkenlerin çarpıklık ve basıklık değerleri ile normallik testleriyle anlaşılmaktadır. Bununla birlikte maddelerin normallikten sapma değerleri ile ilgili kesin normlar belirlenmiştir. Örneklem hacmi 300'den büyük örneklemlerde (n=362>300) ölçek boyutları için, z değerlerini dikkate almadan histogramlara ve çarpıklık ve basıklık mutlak değerlerine bakılabilir. Çarpıklık değer 2'den küçük bir mutlak eğrilik değeri veya basıklık değeri 7'den küçük bir mutlak değer, bu değerlerin normal dağılım kriterlerini karşılaştığı varsayılır (Kim, 2013, s. 53). Kabul edilebilir Çarpıklık ve basıklık değerlerinin kabul edilebilirlik aralıklarına ilişkin literatürde farklı görüşler bulunmaktadır. (George \& Mallery, 2010)George ve Mallery (2010) -1,96 ve +1,96 aralığını normal dağılım için 
S. Kılıç - O. Bayraktar 13/4 (2021) 3026-3043

kabul edilebilir bulurken Gürbüz (2019: 30) -3 ve +3 arasındaki çarpıklık basıklık değerlerinin normal dağılım için kabul edilebilir olduğunu belirtmektedir.

Tablo 5. Ölçek Puanlarına Ait Normallik Sınaması Sonuçları

\begin{tabular}{|c|c|c|c|c|c|c|c|c|c|}
\hline & \multirow[b]{2}{*}{$\mathbf{N}$} & \multirow[b]{2}{*}{ Min. } & \multirow[b]{2}{*}{ Max. } & \multirow[b]{2}{*}{ Ort. } & \multirow[b]{2}{*}{ SS } & \multicolumn{2}{|c|}{ Çarpıklık } & \multicolumn{2}{|c|}{ Basıklık } \\
\hline & & & & & & 营 & 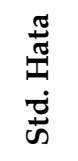 & 岕 & 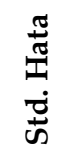 \\
\hline Öğrenme Motivasyonu & 362 & 2,00 & 5,00 & 4,12 &, 53 &,- 622 & ,128 & 1,705 & ,256 \\
\hline $\begin{array}{l}\text { Eğitimden Beklenen Bireysel } \\
\text { Kazançlar }\end{array}$ & 362 & 1,00 & 5,00 & 3,30 &, 79 &,- 447 & ,128 & 191 & ,256 \\
\hline $\begin{array}{l}\text { Eğitim İçin Algılanan Yönetici } \\
\text { Desteği }\end{array}$ & 362 & 1,00 & 5,00 & 3,58 & 85 & $-1,019$ & ,128 & ,932 & ,256 \\
\hline Algılanan Ĕ̆itim Fırsatları & 362 & 1,00 & 5,00 & 3,48 & 87 &,- 761 & ,128 & ,221 & ,256 \\
\hline $\begin{array}{l}\text { Eğitim İçin Algılanan Çalışma } \\
\text { Arkadaşları Desteği }\end{array}$ & 362 & 1,33 & 5,00 & 3,70 & ,66 &,- 656 & ,128 & ,989 & ,256 \\
\hline Kariyer Uygulamaları & 362 & 1,00 & 5,00 & 3,37 &, 89 &,- 732 & ,128 &,- 042 & ,256 \\
\hline Adanmışlık & 362 & 1,00 & 6,00 & 4,24 & 1,22 &,- 560 & ,128 &,- 322 & ,256 \\
\hline Yoğunlaşma & 362 & 1,00 & 6,00 & 4,07 & 1,07 &,- 244 & 128 &,- 131 & ,256 \\
\hline Dinçlik & 362 & 1,25 & 6,00 & 4,26 & ,93 &,- 214 & 128 &,- 032 & ,256 \\
\hline
\end{tabular}

Tablo 5'te elde edilen çarpıklık ve basıklık değerlerine göre, ölçeklerin alt boyut puanlarının normal dağılım gösterdiği tespit edilmiştir. Bundan dolayı normallik dağılımı gerektiren Tek Yönlü Varyans Analizinden yararlanılmıştır. Değişkenle arasındaki etki ise yapısal eşitlik modeli ile test edilmiştir. Testler \%95 güvenilirlikle uygulanmıştır.

\subsection{Bulgular}

Gerçekleştirilen anket uygulanması sonucunda elde edilen verilerin analizi SPSS - AMOS 25.0 yazılımı ile gerçekleştirilmiştir. Katılımcılarla ilgili demografik bilgiler Tablo 6'da gösterilmiştir.

Tablo 6. Katılımcilara Ait Demografik Özelliklerin Frekans ve Yüzde Değerleri

\begin{tabular}{|c|c|c|c|}
\hline & & $\mathbf{N}$ & $\%$ \\
\hline \multirow[t]{4}{*}{ Yaş } & $22-30$ yaş & 106 & 29 \\
\hline & $31-40$ yaş & 195 & 54 \\
\hline & 41 yaş ve üzeri & 61 & 17 \\
\hline & Toplam & 362 & 100 \\
\hline \multirow[t]{4}{*}{ Eğitim durumu } & Ön lisans & 26 & 7,2 \\
\hline & Lisans & 250 & 69,1 \\
\hline & Lisansüstü & 86 & 23,8 \\
\hline & Toplam & 362 & 100,0 \\
\hline \multirow[t]{4}{*}{ Statü } & 3 yildan az & 53 & 15 \\
\hline & $4-7$ yil & 160 & 44 \\
\hline & 8 yıldan fazla & 149 & 41 \\
\hline & Toplam & 362 & 100 \\
\hline
\end{tabular}


S. Kılıç - O. Bayraktar 13/4 (2021) 3026-3043

\begin{tabular}{|c|c|c|c|}
\hline \multirow[t]{4}{*}{ Kıdem } & 3 yildan az & 35 & 10 \\
\hline & $4-7$ yil & 104 & 29 \\
\hline & 8 yıl ve üzeri & 223 & 62 \\
\hline & Toplam & 362 & 100 \\
\hline \multirow[t]{5}{*}{ Görev } & Üst kademe yönetici & 13 & 4 \\
\hline & Orta kademe yönetici & 78 & 22 \\
\hline & Alt kademe yönetici & 58 & 16 \\
\hline & Yönetici değil & 213 & 59 \\
\hline & Toplam & 362 & 100 \\
\hline \multirow[t]{3}{*}{ Çalışılan Lokasyon } & Genel müdürlük & 233 & 64 \\
\hline & Şube & 129 & 36 \\
\hline & Toplam & 362 & 100 \\
\hline
\end{tabular}

Tablo 6'da, araştırmaya katılanların yaş dağılımına bakıldığında \%29'u (N=106) 22-30 yaş, \%54'ü (N=195) 3140 yaş ve \%17'si (N=61) 41 yaş ve üzerindedir. Eğitim durumu ise katılımcıların \%7,2'si (N=26) ön lisans, $\% 69,1^{\prime} i(N=250)$ lisans ve \%23,8'i (N=86) lisansüstü mezunudur.

Mevcut iş yerindeki çalışma süresi yani statü açısından, katılımcıların \%15'i (N=53) 3 yıldan az, \%44' $\ddot{u}$ (N=160) 4-7 yıl ve \%41'i (N=149) 8 yıldan fazla süredir mevcut işyerinde çalışmaktadır. Toplam çalışma süresi (kıdem) açısından, katılımcıların \%10'u (N=35) 3 yıldan az, \%29'u (N=104) 4-7 yıl ve \%62'si (N=223) 8 yıl ve üzeri süredir iş hayatındadır.

Görev değişkeni açısından, katılımcıların \%4’ü ( $\mathrm{N=13)}$ üst kademe yöneticisi, \%22'si (N=78) orta kademe yöneticisi, \%16'sı (N=58) alt kademe yöneticisi ve \%59'u ( $\mathrm{N=213)} \mathrm{yönetici} \mathrm{olmadığını} \mathrm{belirtmiştir.} \mathrm{Çalışılanın}$ görev yaptığı lokasyon değişkeni açısından, katılımcıların \%64'ü ( $\mathrm{N=223)}$ genel müdürlük ve \%36'sı (N=129) şubede çalıştığını belirtmiştir.

Tablo 7. Modelin Hipotez Testi Sonuçları

\begin{tabular}{|c|c|c|c|c|c|}
\hline Yol & & & $\beta$ & Hipotez & Sonuç \\
\hline Öğrenme Motivasyonu & $\rightarrow$ & Dinçlik & $0,44^{*}$ & $\mathrm{H}_{1.1}$ & Kabul Edildi \\
\hline Öğrenme Motivasyonu & $\rightarrow$ & Adanmışlık & $0,44^{*}$ & $\mathrm{H}_{1.2}$ & Kabul Edildi \\
\hline Öğrenme Motivasyonu & $\rightarrow$ & Yoğunlaşma & $0,39^{*}$ & $\mathrm{H}_{1.3}$ & Kabul Edildi \\
\hline Beklenen Bireysel Kazanç Algısı & $\rightarrow$ & Dinçlik & $0,39 *$ & $\mathrm{H}_{1.4}$ & Kabul Edildi \\
\hline Beklenen Bireysel Kazanç Algısı & $\rightarrow$ & Adanmışlık & $0,50^{*}$ & $\mathrm{H}_{1.5}$ & Kabul Edildi \\
\hline Beklenen Bireysel Kazanç Algısı & $\rightarrow$ & Yoğunlaşma & $0,34^{*}$ & $\mathrm{H}_{1.6}$ & Kabul Edildi \\
\hline Yönetici Desteği Alg1sı & $\rightarrow$ & Dinçlik & $0,39^{*}$ & $\mathrm{H}_{1.7}$ & Kabul Edildi \\
\hline Yönetici Desteği Algısı & $\rightarrow$ & Adanmışlık & $0,49^{*}$ & $\mathrm{H}_{1.8}$ & Kabul Edildi \\
\hline Yönetici Desteği Alg1sı & $\rightarrow$ & Yoğunlaşma & $0,34^{*}$ & $\mathrm{H}_{1.9}$ & Kabul Edildi \\
\hline Yetiştirme Fırsatları Algısı & $\rightarrow$ & Dinçlik & $0,36^{*}$ & $\mathrm{H}_{1.10}$ & Kabul Edildi \\
\hline Yetiştirme Fırsatları Algısı & $\rightarrow$ & Adanmışlık & $0,46^{*}$ & $\mathrm{H}_{1.11}$ & Kabul Edildi \\
\hline Yetiştirme Fırsatları Algısı & $\rightarrow$ & Yoğunlaşma & $0,36^{*}$ & $\mathrm{H}_{1.12}$ & Kabul Edildi \\
\hline Çalışma Arkadaşları Desteği Algısı & $\rightarrow$ & Dinçlik & $0,25^{*}$ & $\mathrm{H}_{1.13}$ & Kabul Edildi \\
\hline Çalışma Arkadaşları Desteği Algısı & $\rightarrow$ & Adanmışlık & $0,22^{*}$ & $\mathrm{H}_{1.14}$ & Kabul Edildi \\
\hline Çalışma Arkadaşları Desteği Algısı & $\rightarrow$ & Yoğunlaşma & $0,16^{*}$ & $\mathrm{H}_{1.15}$ & Kabul Edildi \\
\hline Kariyer Uygulamaları & $\rightarrow$ & Dinçlik & $0,40^{*}$ & $\mathrm{H}_{2.1}$ & Kabul Edildi \\
\hline Kariyer Uygulamaları & $\rightarrow$ & Adanmışlık & $0,52^{*}$ & $\mathrm{H}_{2.2}$ & Kabul Edildi \\
\hline Kariyer Uygulamaları & $\rightarrow$ & Yoğunlaşma & $0,35^{*}$ & $\mathrm{H}_{2.3}$ & Kabul Edildi \\
\hline
\end{tabular}

${ }^{*} \mathrm{p}<0,05 ;$ 
Tablo 7'de oluşturulan modele ilişkin hipotezlerin bulguları yer almaktadır. Bu kapsamda, öğrenme motivasyonunun adanmışlı üzerinde $\beta=0,44$ düzeyinde $(p<0,05)$, yoğunlaşma üzerinde $\beta=0,39$ düzeyinde $(p<0,05)$ ve dinçlik üzerinde $\beta=0,44$ düzeyinde $(p<0,05)$ etkili olduğu görülmektedir. Bu sonuçlar Bucley ve Caple (2009)'ın kuramsal olarak belirttiği, öğrenme motivasyonu ile performans ilişkisini destekler niteliktedir.

Yetiştirmeden beklenen bireysel kazançların adanmışlık üzerinde $\beta=0,50$ düzeyinde $(p<0,05)$, yoğunlaşma üzerinde $\beta=0,34$ düzeyinde $(p<0,05)$ ve dinçlik üzerinde $\beta=0,39 \quad(p<0,05)$ düzeyinde etkili olduğu görülmektedir. Bu sonuçlar Noe ve Wilk (1993)'in kuramsal olarak belirttikleri yetiştirme uygulamaları ile bireysel kazanç beklentisi ilişkisi olduğunu doğrular niteliktedir.

Yetiştirme için algılanan yönetici desteğinin adanmışlık üzerinde $\beta=0,49$ düzeyinde $(p<0,05)$, yoğunlaşma üzerinde $\beta=0,34$ düzeyinde $(p<0,05)$ ve dinçlik üzerinde $\beta=0,39$ düzeyinde $(p<0,05)$ etkili olduğu görülmektedir. Bu sonuçlar Noe (2009)'nin kuramsal olarak belirttiği, yönetici ile yetiştirme arasındaki ilişkiyi doğrular niteliktedir.

Algılanan yetiştirme fırsatlarının adanmışlık üzerinde $\beta=0,46$ düzeyinde $(p<0,05)$, yoğunlaşma üzerinde $\beta=0,36$ düzeyinde $(p<0,05)$ ve dinçlik üzerinde $\beta=0,36$ düzeyinde $(p<0,05)$ olarak gerçekleşmiştir. Bu sonuçlar Sabuncuoğlu (2007) ve Dysvik ve Kuvas (2008)'in araştırma sonuçları ile uyumludur.

Yetiştirme için algılanan çalışma arkadaşları desteğinin adanmışlık üzerinde $\beta=0,22$ düzeyinde $(p<0,05)$, yoğunlaşma üzerinde $\beta=0,16$ düzeyinde $(p<0,05)$ ve dinçlik üzerinde $\beta=0,25$ düzeyinde $(p<0,05)$ pozitif bir etkisinin olduğu tespit edilmiştir. Bu sonuçlar Noe (2009)'nin kuramsal olarak ortaya koyduğu yetiştirme uygulamaları ile arkadaş desteği ilişkisini destekler niteliktedir.

Kariyer uygulamalarının ise adanmışlık üzerinde $\beta=0,52$ düzeyinde $(p<0,05)$, yoğunlaşma üzerinde $\beta=0,35$ düzeyinde $(\mathrm{p}<0,05)$ dinçlik üzerinde $\beta=0,40$ düzeyinde $(\mathrm{p}<0,05)$ pozitif bir etkisinin olduğu görülmektedir. $\mathrm{Bu}$ sonuçlar Tladinyane ve Merwe (216), Ali, Bashir ve Mehreen (2019) ve Alabooda ve Manakkattilb (2020; Opadeyi ve Akpa (2021); Nedeem vd., (2017)'nin araştırma sonuçları ile uyumludur.

\section{SONUÇ VE ÖNERILER}

Bu araştırmada yetiştirme ve kariyer uygulanmalarının çalışan tutkunluğu üzerindeki etkisine dair hipotezler test edilmiştir. Çalışan tutkunluğu; dinçlik, adanmışlık ve yoğunlaşma olmak üzere üç alt boyuttan oluşmaktadır. Yetiştirme değişkenin ise öğrenme motivasyonu, beklenen bireysel kazanç, yönetici desteği algısı, yetiştirme fırsatları algısı ve çalışma arkadaşları desteği olmak üzere beş alt boyutu bulunmaktadır. Yetiştirme ölçeği boyutları kuramsal olarak Noe (2009)'nin çalışmasına dayanmaktadır. Araştırmada yetiştirmenin alt boyutlarıyla, çalışan tutkunluğunun alt boyutları arasındaki hipotezlerin tümü desteklenmiştir. Yetiştirme ve çalışan adanmışlığı ile ilgili bulgular Bucley ve Caple (2009), Noe ve Wilk (1993) ve Noe (2009)'nin kuramsal önermelerini desteklemektedir. Bu araştırmada yetiştirmenin alt boyutlarıyla, çalışan tutkunluğunun alt boyutlarına ilişkin hipotezlerin tümünün desteklenmiş olması, bağımlı değişken olan çalışan tutkunluğu alt boyutlarının paralel hareket ettiğine dair işaret vermektedir. Bir çalışan adanmışlık duygusuna sahipse aynı zamanda dinçlik ve yoğunlaşma davranışlarını da göstermektedir. Ölçeği geliştiren yazarların da önerdiği gibi tek boyutlu kısa versiyonu kullanılabilir (Güler, Çetin, \& Önerisi, 2019).

Yetiştirme değişkeninde esas sonuç alıcı boyutun öğrenme motivasyonu olduğu söylenebilir. Diğer dört boyut; beklene bireysel kazanç, yönetici desteği, yetiştirme fırsatları ve çalışma arkadaşları desteği öğrenme motivasyonunu harekete geçiren unsurlardır. Bu verilerden hareketle, işyerinde yetiştirme ile çalışan tutkunluğu arasındaki ilişkide istenilen sonucun alınabilmesi için yönetici desteği, çalışma arkadaşları desteği ve yetiştirme fırsatlarının birlikte işlemesi gerekir. Bu üç boyut çalışanın etkisi dışındadır. Çalışanın bu alanlardaki algısının olumlu olması, bireysel kazanç beklentisiyle birleştiğinde öğrenme motivasyonu da gerçekleşecektir.

Araştırmanın ikinci modeli, kariyer uygulamaları ile çalışan tutkunluğu ilişkisinin araştırılasıdır. Bu ilişkiye ilişkin hipotezler de tüm alt boyutlarıyla desteklenmiştir. Bu sonuçlar Tladinyane ve Merwe (216), Ali, Bashir ve Mehreen (2019) ve Alabooda ve Manakkattilb (2020; Opadeyi ve Akpa (2021); Nedeem vd., (2017)'nin araştırma sonuçları ile uyumludur. 
Kariyer planlama, sürece dahil olan çalışanları bir sonraki pozisyona hazırlamak için bir dizi yetiştirme ve geliştirme faaliyetlerini de içerir. Bu nedenle yetiştirme uygulamalarının çalışan tutkunluğunu artırdığı bir iş ortamında kariyer uygulamamalarının da aynı etkiyi göstermesi beklenen bir sonuçtur. Yetiştirme ve kariyer uygulamalarının ikisinin birden çalışma tutkunluğu üzerinde etkili olmasını, giriş bölümünde vurgu yapıldı̆̆ı gibi, bankacılık sektöründe insan kaynakları uygulamalarının bütünsel olarak gelişmişlik düzeyi ile açıklamak mümkündür.

Araştırmacılar için öneriler. Bu araştırmada, çalışan adanmışlığının yetiştirme ve kariyer uygulamalarından etkilenme durumu bankacılık sektöründe araştırılmış, kuramsal önermeler araştırma sonuçları ile doğrulanmıştır. Araştırmacılar için birinci önerimiz, aynı araştırma modelinin hem bankacılık sektöründe hem de başka sektörlerde tekrarlanmasıdır. Yetiştirme ve kariyer uygulamalarının hem örgütler hem de çalışanlar açısından önemini koruyacağı kanaatindeyiz.

İkinci öneri, insan kaynaklarının performans yönetimi ücret ve ödüllendirme diğer insan kaynakları işlevlerinin çalışan adanmışlığı üzerindeki etkisinin araştırılmasıdır. Diğer taraftan yapılan analizler sonucunda daha tecrübeli olan çalışanlarının çalışan tutkunluğu düzeyinin diğerlerine göre daha yüksek olduğu anlaşılmıştır. Bu durumun sebepleri ile daha tecrübesiz veya çalışma hayatına yeni başlayan iş görenlerin çalışan tutkunluğu düzeyini hangi faktörlerin artırabileceği ile ilgili araştırmalar yapılabilir.

Uygulayıcılar için öneriler. Tutkunluğun iş performansını doğrudan etkilemesi nedeniyle işine tutku ile sarılan çalışanlara sahip olmak her işletmenin arzu ettiği bir durumdur. Bu araştırmanın da teyit ettiği gibi, yetiştirme ve kariyer uygulamalarının çalışan adanmışlığı üzerindeki etkisi farklı sektörlerde yapılan birçok araştırma ile desteklenmektedir. Bu veriyi göz önünde bulundurarak uygulayıcıların işletmelerindeki yetiştirme ve kariyer uygulamalarını bu açıdan gözden geçirmelerinde büyük yarar bulunmaktadır.

Uygulamacılar açısından dikkate alınması gereken bir durum yetiştirme değişkenin alt boyutlarıdır. Yetiştirme uygulamalarının, çalışan tutkunluğu üzerinde etkisinin olabilmesi için bu alt boyutların birlikte uygulanması gerekmektedir.

\section{KAYNAKÇA}

Alabooda, A., \& Manakkattilb, S. (2020). The relationship between career maximization and employee engagement. Management Science Letters(10), 2597-2602.

Ali, Z., Bashir, M., \& Mehreen, A. (2019). Managing Organizational Effectiveness through Talent Management and Career Development: The Mediating Role of Employee Engagement. Journal of Management Sciences, 6(1), 62-78.

Alnıaçık, E. (2013). Kariyer Yönetimi. O. Erdil, \& H. Özkutlu içinde, İnsan Kaynakları Yönetimi (s. 275-303). İstanbul: Lisans Yayıncılık.

Alola, U. V., \& Alafeshat, R. (2021). The impact of human resource practices on employee engagement in the airline industry. Journal of Public Affairs, https://doi.org/10.1002/pa.2135.

Ayub, N. B., \& Islam, M. K. (2018). The Effects of Employee Engagement on Employee Performance in the Hotel Industry in Kelantan. Global Business and Management Research: An International Journal, 10(3), 828-838.

Bartlett, K. (1999). The relationship between training and organizational commitment in the health care field. Yayınlanmamış Doktora Tezi, University of Illinois.

Bhatti, M., Mat, N., \& Juhari, A. (2018). Effects of job resources factors on nurses job performance (mediating role of work engagement). International Journal of Health Care Quality Insurance, 31(8), 1000-1013.

Bingöl, D. (2019). İnsan kaynakları yönetimi (Güncellenmiş 11. b.). İstanbul: Beta Basım Yayım Dağıtım A.Ş.

Buckley, R., \& Caple, J. (2009). The Theory and Practice of Training. London: Kogan Page.

Budak, G. (2016). Yetkinliğe Dayalı İnsan Kaynakları Yönetimi. İstanbul: Nobel. 
S. Kılıç - O. Bayraktar 13/4 (2021) 3026-3043

Cartera, W. R., Paul L. Nesbitb, R. J., \& Sung, L.-K. (2018). The effects of employee engagement and self-efficacy on job performance: a .longitudinal field study. The International Journal of Human Resource Management, 29-17, 2483-2502.

Chadha, D. (2018). A Study of Training and Development Practices in Service Sector in Relation to Employee Engagement across Delhi and NCR. International Journal of Human Resource Development and Management, 8(1), 1-11.

Chandani, A., Mehta, M., Mall, A., \& Khokhar, V. (2016). Employee Engagement: A Review Paper on Factors Afecting Employee Engagement. Indian Journal of Science and Technology, 9(15), 1-7.

Chaudhry, N. I., Jariko, M. A., Mushtaque, T., Mahesar, H. A., \& Ghani, Z. (2017). Impact of working environment and training \& development on organization performance through meiating role of employee engagement and job satisfaction. European Journal of Training and Development Studies, 4(2), 33-48.

Cinnioğlu, H., \& Saçli, Ç. (2019). Restoran Çalışanlarının Hizmetkâr Liderlik Algıları ile İşe Adanmışlık Düzeyleri Arasındaki İlişki. İşletme Araştırmaları Dergisi, 11(3), 1769-1778.

Çokluk, Ö., Şekercioğlu, G., \& Büyüköztürk, Ş. (2018). Sosyal Bilimler İçin Çok Değgişkenli İstatistik SPSS ve LISREL Uygulamaları. Ankara: Pegem Akademi.

Dysvik, A., \& Kuvaas, B. (2008). The relationship between perceived training opportunities, work motivation and employee outcomes. The relationship between perceived training opportunities, work motivation ..., 12(3), 138-157.

George, D., \& Mallery, M. (2010). SPSS for Windows Step by Step: A Simple Guide and Reference. Boston: Pearson.

Green, P. I., Finkel, E. J., Fitzsimons, G. M., \& Ginoa, F. (2017). The energizing nature of work engagement: Toward a new need-based theory of work motivation. Research in Organizational Behavior(37), 1-18.

Güler, M., Çetin, F., \& Önerisi, H. N.-6. (2019). İşe Tutulma Ölçeği Çok Kısa Versiyonu (UWES-3) Geçerlilik ve. İ̧̧ ve Insan Dergisi I, 189-197.

Gürbüz, S. (2019). Amos ile Yapısal Eşitlik Modellemesi. Ankara: Seçkin.

Iacobucci, D. (2010). Structural equations modeling: Fit Indices, sample size, and advanced topics. Journal of Consumer Psychology, 20, s. 90-98.

İlhan, M., \& Çetin, B. (2014). LISREL ve AMOS Programları Kullanılarak Gerçekleştirilen Yapısal Eşitlik Modeli (YEM) Analizlerine İlişkin Sonuçların Karşılaştırılması. Eğitimde ve Psikolojide Ölçme ve Değerlendirme Dergisi, 5(2), 26-42.

İnce, A. R. (2016). Algılanan örgütsel desteğin işe adanmışlık üzerindeki etkisinde yönetici desteğinin aracılık rolü. Elektronik Sosyal Bilimler Dergisi, 15(57), 649-660.

Johnson, K. R., Park, S., \& Bartlett, K. (2018). Perceptions of customer service orientation, training, and employee engagement in Jamaica's hospitality sector. European Journal of Training \& Development, 42(3/4), 191-209.

Kahn, W. (1990). Psychological conditions of personal engagement and disengagement at work. The Academy of Management Journal, 33(4), s. 692-724.

Kapil, K., \& Rastogi, R. (2017). Job embeddedness and work engagement as predictors of job performance. Journal of Strategic Human Resource Management, 6(3), 28-33.

Kartal, N. (2018). Sağlık Çalışanlarında İşe Cezbolma: Üniversite, Kamu ve Özel Hastanelerde Bir Uygulama. Hacettepe Sağllk İdaresi Dergisi, 20(3), 329-345.

Kim, H.-Y. (2013). Statistical notes for clinical researchers: assessing normal distribution (2) using skewness and kurtosis. Restorative Dentistry \& Endodontics, 38(1), s. 52-54.

Knowles, M., Swanson, R., \& Holton, E. (2015). Yetişkin Eğitimi. (O. Gündüz, Çev.) İstanbul: Kaknüs.

Maslach, C., Schaufeli, W., \& Leiter, M. (2001). Job burnout. Annu. Rev. Psychol., 52, s. 397-422. 
Memon, M. A., Salleh, R., \& Baharom, M. N. (2016). The Link between Training Satisfaction, Work Engagement and Turnover Intention. European Journal of Training and Development, 40(6), 407-429.

Nadeem, M. H., Ghani, .. M., \& Shah, S. A. (2017). A Study on Employee Engagement through Employee Development in the Banking Sector of Pakistan: Case Study of a Private Bank- A Project of Abu Dhabi Business Consortium. Global Social Sciences Review, 2(2), 137 - 145.

Nadeem, M. H., Ghani, M. U., \& Shah, S. A. (2017). Study on Employee Engagement through Employee Development in the Banking Sector of Pakistan: Case Study of a Private Bank- A Project of Abu Dhabi Business Consortium. Global Social Sciences Review, 2(2), 137-145.

Noe, R. (2009). İnsan kaynaklarının eğitimi ve geliştirilmesi. (C. Çetin, Çev.) İstanbul: Beta Basım Yayım Dağıtım A.Ş.

Noe, R. A., \& Wilk, S. L. (1993). Investigation of Factors That Influence Employees' Participation in Development Activities. Journal of Applied Pschology, 291-302.

Obuobisa-Darko, T. (2020). Leaders' Behaviour as a Determinant of Employee Performance in Ghana: the Leaders' Behaviour as a Determinant of Employee Performance in Ghana: the Mediat. Public Organization Review(20), 597-611.

Ogruk, G., \& Anderson, T. (2018). The impact of work engagement and authenticity on employees' job performance and well-being: Non-selfreport measures of in-role and extra-role jobperformance. New Zealand Journal of Human Resources Management, 18(1), 47-64.

Opadeyi, M., \& Akpa, V. (2021). Career Development and Employee Engagement in Selected Deposit Money Banks in Ogun. The Strategic Journal of Business \& Change Management, 8(2), 326-336.

Öztürk, M., \& Vatansever, K. (2020). Örgütsel Adalet ve Örgütsel Güvenin İşe Adanmışlık Üzerindeki Etkilerinin Belirlenmesi: Alanya Belediyesi Çalışanları Üzerine Bir Araştırma. İşletme Araştırmaları Dergisi, 12(4), 3613-3632.

Rashid, H. A., Asad, A., \& Ashraf, M. M. (2011). Factors Persuading Employee Engagement and Linkage of EE to Personal \& Organizational Performance. Interdisciplinary Journal of Contemporary Research in Business, 2(5), 98-105.

Robbins, S. P., \& Judge, T. A. (2019). Örgütsel Davranış. (İ. Erdem, Çev.) İstanbul: Nobel.

Robertson-Smith, G., \& Markwick, C. (2017). Employee Engagement A review of current thinking. Brighton: Institute for Employment Studies.

Sabuncuoğlu, E. T. (2007). Eğitim, Örgütsel Bağlılık ve İşten Ayrılma Niyeti Arasındaki İlişkilerin İncelenmesi. Ege Akademik Bakış, 7(2), 621-636.

Sawasdee, A., Saengcha, S., \& Jermsittiparsert, K. (2020). he Role of Emotional Demands, Supervisor Support and Training Opportunities towards Work Engagement among Employees in Pharmaceutical Companies of Thailand. Systematic Review Pharmacy , 11(3), 176-184.

Saxena, V., \& Srivastava, R. K. (2015). Impacof employee engagement on employee performance-case of manufacturing sectors. International Journal of Management Resaerch and Business Strategy, 4(2), 140-174.

Schaufeli, W., \& Bakker, A. (2004). Utrecht Work Work Scale. Occupational Health Psychology Unit, s. 1-59. Aralık 2020 tarihinde https://www.wilmarschaufeli.nl/publications/Schaufeli/Test\%20Manuals/Test_manual_UWES_Engli sh.pdf adresinden alınd 1

Schaufeli, W., Bakker, A., \& Salanova, M. (2006). The measurement of work engagement with a short questionnaire: A cross-national study. Educational and Psychological Measurement, 66(4), s. 701-716.

Schaufeli, W., Salanova, M., González-Romá, V., \& Bakker, A. (2002). The measurement of engagement and burnout: A two sample confirmatory factor analytic approach. Journal of Happiness Studies, 3, s. 71-92. 
S. K1lıç - O. Bayraktar 13/4 (2021) 3026-3043

Semwal, M., \& Dhyani, A. (2017). Impact of trining and career development on employee angagement A study using OCM and UWES Measurment Scales. NICE Journal of Business, 12(1), 85-101.

Sepahvand, R., \& Khodashahri, R. B. (2021). Strategic Human Resource Management Practices and Employee Retention: A Study of the Moderating Role of Job Engagement. Iranian Journal of Management Studies, 14(2), 437-468.

Siddiqui, D. A., \& Sahar, N.-u. (2019). The Impact of Training and Development and Communication on Employee Engagement - A Study of Banking Sector. Business Management and Strategy, 10(1), 23-40.

Stone, R. J. (2008). Human Resource Management. Milton Old: Wiley.

Tanışman, İ. (2018). İşletmelerde eğitim ve geliştirme uygulamalarının iş tatminine etkisi: Bir alan araştırması. Yayınlanmamış Yüksek Lisans Tezi, İstanbul Üniversitesi, Sosyal Bilimler Enstitüsü, İstanbul.

Tladinyane, R., \& Merwe, M. v. (2016). Career adaptability and employee engagement of adults employed in an insurance company: An exploratory study. SA Journal of Human Resource Management, 14(1), 1-9.

Tokmak, M. (2021). İş Aile Çatışması ve Çalışmaya Tutkunluk Arasındaki İlişkiye Yönelik Bir Araştırma. Afyon Kocatepe Üniversitesi Sosyal Bilimler Dergisi, 23(1), 113-124.

Turgut, T. (2011). Çalışmaya tutkunluk: İş yükü, esnek çalışma saatleri, yönetici desteği ve iş-aile çatışması ile ilişkileri. Atatürk Üniversitesi İktisadi ve İdari Bilimler Dergisi, 25(3-4), 155-179.

Yaşlığlu, M. M. (2017). Sosyal Bilimlerde Faktör Analizi ve Geçerlilik: Keşfedici ve Doğrulayıcı Faktör Analizlerinin Kullanılması. İstanbul Üniversitesi İşletme Fakültesi Dergisi, 46(Özel Sayı), 74-85.

Yıldız, D. (2017). Analyzing effects of organizational career management activities on employees' career outcomes. Yayınlanmamış Doktora Tezi, Bahçeşehir Üniversitesi, Sosyal Bilimler Enstitüsü, İstanbul.

Yıldız, N. (2011). İnsan Kaynaklarında Ĕ̆itim ve Geliştirme Faaliyetlerinin Örgütsel Vatandaşlık Davranışına Etkileri Üzerine Uygulamalı Bir Araştırma. Konya: Seçuk Üniversitesi Sosyal Bilimler Enstitüsü, Basılmamış Yüksek Lisans Tezi.

Yongxing, G., Hongfei, D., \& X. B. (2017). Work engagement and job performance: the moderating role of perceived organizational support. Anales de Psicología, 33(3), 708-713. 